\title{
Segmental distribution of $\alpha$-glucosidase, ornithine decarboxylase and polyamines in the human epididymis
}

\author{
K. Purvis and I. Egdetveit \\ Andrology Laboratory, Institute of Pathology, The National Hospital, Oslo, Norway
}

\begin{abstract}
Regional differences in the total activities of the epididymal secretory parameter, $\alpha$-glucosidase, were demonstrated in the $20000 \mathrm{~g}$ supernatants of human epididymal homogenates. A comparison of the enzymic activities in the supernatants and the washings from 12 one centimetre segments of human epididymides indicated an activity peak in segments 3-4 which appeared to be largely intracellular and which presumably reflects the acidic isoenzyme. A second peak in the caudal region, the segmental localization of which was more variable and differed in post-mortem and operation specimens, appeared to be primarily intraluminal. The activities of ornithine decarboxylase (ODC), the rate-limiting enzyme in the polyamine pathway, also exhibited regional differences with higher activities in relatively short segments in both caput and caudal portions. Corresponding alterations were also found in the tissue concentrations of the enzyme products, spermidine and spermine. The increased intracellular activities of ODC and $\alpha$-glucosidase in the distal caput segments presumably reflect the transition of epithelium from the efferent to the epididymal ducts.
\end{abstract}

\section{Introduction}

Specific alterations occur in the biochemistry and function of spermatozoa during epididymal transit. These include changes in the intracellular concentrations of enzymes such as protein methyltransferase (Gagnon et al., 1984), protein carboxylmethylase, and cAMP and cGMP phosphodiesterases (Purvis $e t$ al., 1982) and alterations in various phospholipids (Voglmayr, 1975) and membrane proteins (Olson and Danzo, 1981). Some of these alterations are likely to be related to the gradual acquisition of progressive motility which occurs as spermatozoa pass from the efferent ducts to the cauda epididymis (for review see Bedford, 1975). At least some of these alterations in sperm biochemistry may reflect an interaction between the spermatozoon and components of epididymal secretion, secretory products which may be produced in discrete regions of the organ. It is significant, in this respect, that specific proteins are present and absent from the luminal fluid of different epididymal segments (Sylvester et al., 1984; Ross et al., 1990) and that histological studies imply regional differences in cellular function (Holstein, 1980).

The polyamines, spermidine and spermine, are believed to be general mediators of RNA and protein synthesis in somatic cells (Russell, 1980) and ornithine decarboxylase (ODC; EC 3.5.3.1) is a rate-limiting intracellular enzyme in their biosynthesis (Russell, 1980). This enzyme can be rapidly activated by testosterone in androgen target tissues (Pegg et al., 1970; Purvis et al., 1986). Seminal $\alpha$-glucosidase (EC 3.2.1.20) is acknowledged to be a marker of human epididymal secretory function (Guérin $e t$ al., 1986; Casano et al., 1987; Cooper et al., 1988). Although the role of $\alpha$-glucosidase in sperm function is still unknown, it has

Received 5 August 1992. been suggested that it may be involved in the modification of surface glycoproteins during epididymal transit, thus facilitating sperm-ovum interaction (Fournier-Delpech and Courot, 1987).

The aim of the present study was to ascertain whether regional changes in general metabolic activity, reflected in the tissue concentrations of ODC and the polyamines, could be related to the epididymal distribution of one of its secretory products, $\boldsymbol{\alpha}$-glucosidase. Studies on regional alterations in epididymal biochemistry have obvious relevance to our understanding of the processes involved in sperm maturation.

\section{Materials and Methods}

\section{Source of epididymides and initial preparation}

For the measurements of ODC, epididymides were obtained from men undergoing orchidectomy because of prostatic cancer (four cases; median age 62 years; range 58-67 years) and from men after necropsy (two cases; 26 and 36 years). The organs were first dissected free from fat and connective tissue and divided into $1 \mathrm{~cm}$ long segments from the testicular end (12 segments in all; Fig. 1). Segments 1-4, 5-6, 7-10 and 11-12 corresponded approximately to the caput, corpus and caudal regions of the epididymis and to the vas deferens, respectively. Epididymides with any observable pathology, including atrophy, were excluded from the study. For the $\alpha$-glucosidase and polyamine measurements, organs were obtained after necropsy from men involved in traffic accidents (seven cases; mean 23 years; range $21-40$ years). In all cases, the epididymides were removed within $48 \mathrm{~h}$ of death. In the interim period, the cadavers were maintained at $4^{\circ} \mathrm{C}$. The epididymal segments 


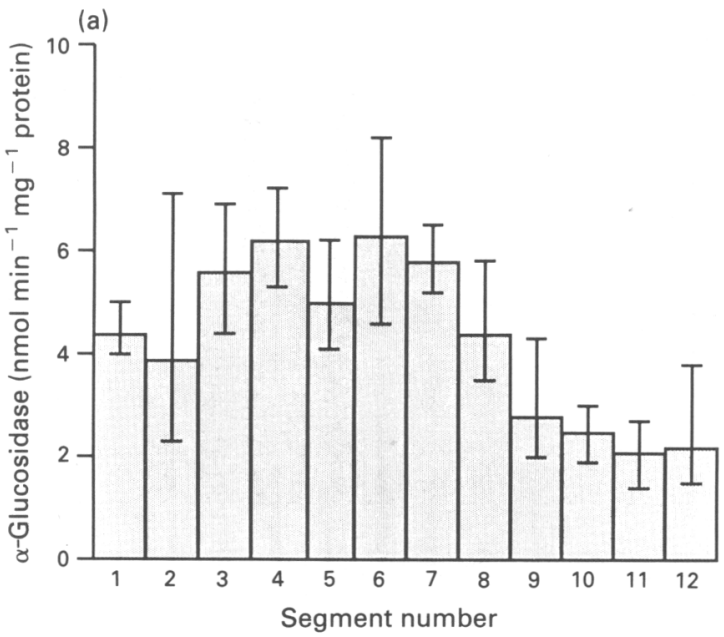

(b)

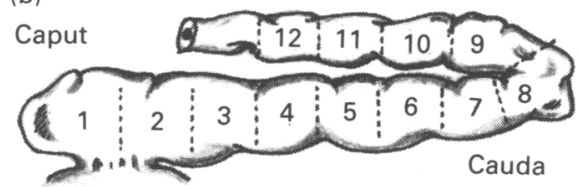

Fig. 1. (a) The distribution of $\alpha$-glucosidase in $20000 \mathrm{~g}$ supernatants prepared from human epididymal segments (geometric means and $95 \%$ confidence limits; $n=7$ ) from organs obtained at necropsy. (b) The epididymides were divided into 12 segments of $1 \mathrm{~cm}$ lengths. Enzymic activity was expressed in terms of the conversion of substrate min $^{-1}$ $\mathrm{mg}^{-1}$ protein in the epididymal supernatants.

were homogenized for $45 \mathrm{~s}$ in 10-20 volumes (depending on the size of the tissue fragments) of Tris- $\mathrm{HCl}$ buffer $\left(50 \mathrm{mmol} \mathrm{l}^{-1}\right.$. $\mathrm{pH}$ 7.2) containing $5 \mathrm{mmol}$ dithiothreitol $\mathrm{I}^{-1}$ (DTT), $0.1 \mathrm{mmol}$ EDTA $1^{-1}$ and $0.2 \mathrm{mmol}$ pyridoxal phosphate $1^{-1}$ (Sigma Chemical Co., MO) followed by centrifugation at $20000 \mathrm{~g}$ for $30 \mathrm{~min}$. The resulting supernatants were then stored frozen at $-70^{\circ} \mathrm{C}$

\section{a-Glucosidase activity in epididymal tissue and secretory compartments}

In one study, single epididymides from three individuals were used to assess the relative proportion of $\boldsymbol{\alpha}$-glucosidase activity in the epididymal tissue and secretion. All three epididymides were obtained after orchidectomy of patients with prostatic cancer. The ages of the donors were 55,59 and 63 years. No form of chemical castration had been initiated prior to the operation. The tissue was transported on ice and processed within $30 \mathrm{~min}$ of removal. After dissection the 12 individual segments were cut into thin slices and washed in $2 \mathrm{ml}$ medium (Dulbecco's medium without calcium and magnesium, Flow Laboratories, Irvine, UK) in Petri dishes $(4.5 \mathrm{~cm}$ diameter) under gentle mixing for $30 \mathrm{~min}$. The washings were aspirated, filtered through nylon mesh $(100 \mu \mathrm{m})$ and centrifuged at $1500 \mathrm{~g}$ for $10 \mathrm{~min}$. The resulting supernatants were then frozen at $-70^{\circ} \mathrm{C}$ until the day of assay. The tissue fragments remaining were pooled and also stored at $-70^{\circ} \mathrm{C}$. They were later homogenized in the same buffer.

\section{Determination of a-glucosidase}

The assay used was that described by Chapdelaine et al. (1978) with minor modifications and is based on the colorimetric determination of $p$-nitrophenol- $\alpha$-D-glucopyranoside (Sigma Chemical Co.). No attempt was made to differentiate between acid and neutral forms of the enzyme as described by Cooper et al. (1988), so that all measurements reflected total enzymic activity in each segment. For the analysis of 100 samples (50 samples in duplicate), a stock solution of the substance $(500 \mathrm{mg}$ in $70 \mathrm{ml}$ potassium phosphate buffer, $0.067 \mathrm{~mol}$ $\mathrm{I}^{-1}, \mathrm{pH}$ 6.8) was first preincubated at $37^{\circ} \mathrm{C}$ for $10 \mathrm{~min}$ with $2.5 \mathrm{mg}$ of reduced glutathione (Aldriche-Chemie, Germany) dissolved in distilled water. Aliquots of the substrate solution $(725 \mu \mathrm{l})$ were then added to tubes containing aliquots $(25 \mu \mathrm{l})$ either of the cytosols or of the washings from the minced segments before homogenization. After mixing, the tubes were incubated for $1.5 \mathrm{~h}$ at $37^{\circ} \mathrm{C}$; distilled water blanks were included in each assay. The reaction was terminated by the addition of $0.1 \mathrm{~mol} \mathrm{Na}_{2} \mathrm{CO}_{3} \mathrm{I}^{-1}(4250 \mu \mathrm{l})$. After mixing, the resulting yellow colour was quantitated colorimetrically at $400 \mathrm{~nm}$, relative to a standard curve prepared with increasing concentrations of $p$-nitrophenol in $\mathrm{Na}_{2} \mathrm{CO}_{3}$ buffer $\left(6-120 \mathrm{nmol} \mathrm{ml}^{-1}\right)$. Units of enzymic activity were defined in terms of the quantity of $p$-nitrophenol (in nmoles) produced per min by $1 \mathrm{ml}$ of $20000 \mathrm{~g}$ supernatant or washings (Fig. 2) or per min per $\mathrm{mg}$ protein in the $20000 \mathrm{~g}$ supernatants (Fig. I).

The rate of hydrolysis of the substrate was linear between 5 and $100 \mu \mathrm{l}$ for the cytosols and for the washings of the minced segments. Linearity was also obtained between 30 and $120 \mathrm{~min}$ of incubation when $25 \mu \mathrm{l}$ was used. The coefficients of interassay variation never exceeded $10 \%$ and intra-assay variation of duplicates was never greater than $6 \%$.

\section{Determination of ornithine decarboxylase}

The assay was based on the measurement of ${ }^{14} \mathrm{CO}_{2}$ liberated from $\left[{ }^{14} \mathrm{C}\right.$ lornithine as described by Kobayashi et al. (1971). This technique has been applied to the measurement of the enzyme in prostatic tissue by Rui et al. (1987). Briefly $1 \mathrm{ml}$ of the $20000 \mathrm{~g}$ supernatant was transferred to $25 \mathrm{ml}$ flasks for the enzyme assay. The reaction was started by the addition of $1 \mathrm{ml}$ buffer containing $25 \mathrm{nmol}$ of L-ornithine and $6 \mathrm{nmol}$ (400000 c.p.m.) of $\left[{ }^{14} \mathrm{C}\right](\mathrm{DL})$-ornithine $\left(58 \mathrm{mCi} \mathrm{mmol}^{-1}\right.$; Amersham, UK). The flasks were closed with rubber stoppers and incubated in a shaking water bath at $37^{\circ} \mathrm{C}$ for $2 \mathrm{~h}$. The reaction was terminated by injecting $1 \mathrm{ml}$ citric acid $\left(2 \mathrm{~mol} \mathrm{l}^{-1}\right)$ through the rubber stopper. It was allowed to stand for a further $60 \mathrm{~min}$ to ensure the complete release of $\mathrm{CO}_{2^{\prime}}$ which was absorbed by a Whatman 17 filter strip containing $50 \mu \mathrm{l}$ of ethanolamine (Sigma) diluted to $33 \%$ in ethylene glycol. The filter strip was placed in a plastic well held by the rubber stopper. After incubation, the paper was transferred to vials containing $10 \mathrm{ml}$ scintillation fluid (Hydroluma, Lumac Systems, USA) and counted. The protein concentrations and the incubation times used in the assay were derived from the linear 
(a)

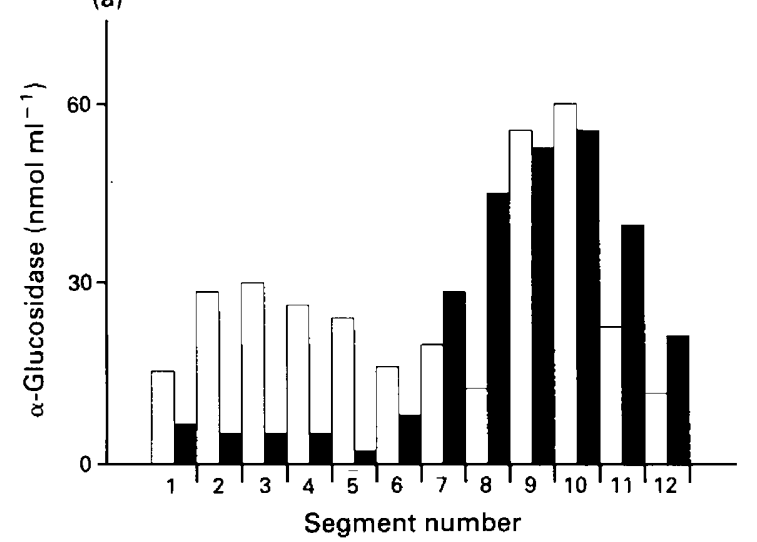

(c)

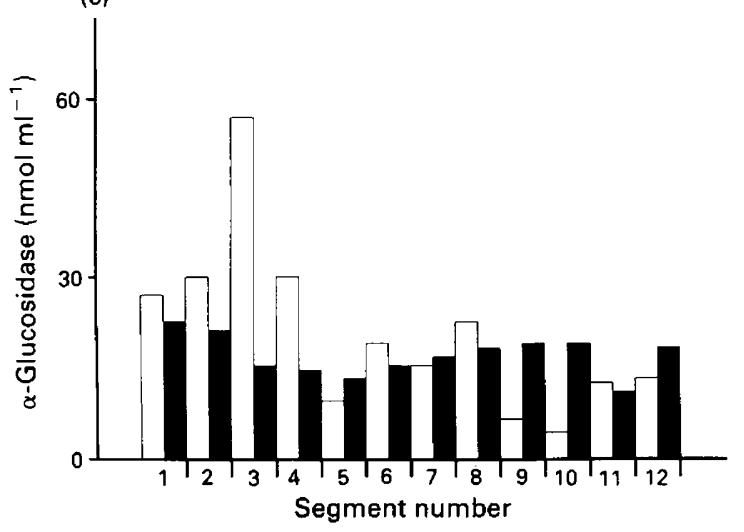

(b)

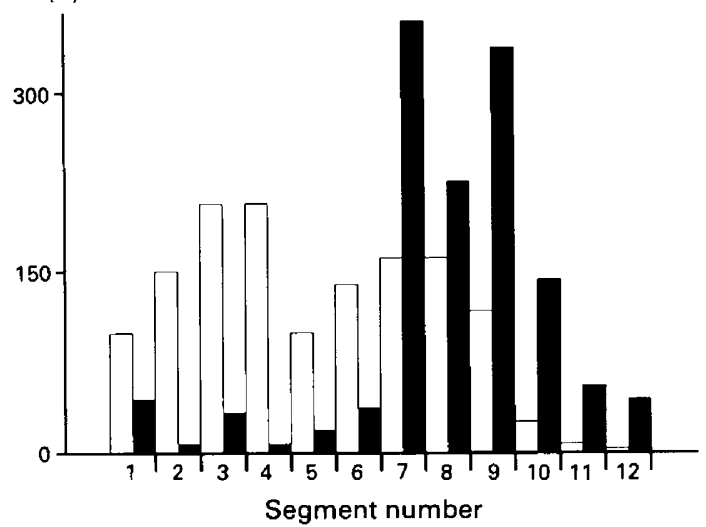

Fig. 2. The distribution of $\alpha$-glucosidase in 12 epididymal segments from three different individuals (a-c) after orchidectomy. Enzymic activity was expressed as nmol of substrate converted $\mathrm{ml}^{-1}$ and measured in the washings from the minced segments ( $)$ and in the $20000 \mathrm{~g}$ supernatants of the remaining tissue fragments ( $\square$ ).

portion of the activity curves, which were linear between 0.5 and $5 \mathrm{mg}$ protein and 0 and $4 \mathrm{~h}$ (data not shown).

\section{Determination of spermidine and spermine}

The method was based on the fluorescent detection of dansylated amine derivatives after HPLC separation and has been described in detail elsewhere (Rui et al., 1985). Epididymal segments were homogenized in 5 volumes of Tris- $\mathrm{HCl}$ buffer (see above) and, after centrifugation at $20000 \mathrm{~g}$ for $30 \mathrm{~min}$, duplicate aliquots of the supernatant $(25 \mu \mathrm{l})$ were mixed with $375 \mu \mathrm{l}$ of internal standard (1,6-diaminohexane, $2.5 \mathrm{nmol} \mathrm{l}^{-1}$ in water) and deproteinized with $100 \mu \mathrm{l} 10 \%$ trichloroacetic acid (TCA) on ice for $20 \mathrm{~min}$, followed by centrifugation at $2000 \mathrm{~g}$ for $30 \mathrm{~min}$. The TCA was then removed from the supernatant by extraction twice with 2.5 volumes of diethyl ether. Duplicate samples $(100 \mu \mathrm{l})$ of the supernatant were mixed with $100 \mathrm{mg}$ $\mathrm{NaHCO}_{3}$ and $100 \mu \mathrm{l}$ dansyl chloride (Sigma; $30 \mathrm{mg}$ in $10 \mathrm{ml}$ acetone). The reaction mixture was allowed to stand overnight in the dark at room temperature. Excess dansyl chloride was removed by the addition of $100 \mu \mathrm{l} \mathrm{L}$-proline $\left(1.3 \mathrm{~mol} \mathrm{l}^{-1}\right.$ in water) followed by a further $30 \mathrm{~min}$ incubation in the dark. The contents of the tubes were then dried at $65^{\circ} \mathrm{C}$ under a stream of air dissolved in $100 \mu \mathrm{l}$ water, and extracted with $500 \mu$ l toluene. An aliquot $(300 \mu \mathrm{l})$ of the toluene phase was evaporated to dryness and dissolved in a final volume of $600 \mu \mathrm{l}$ methanol. A $20 \mu \mathrm{l}$ sample was applied to the column $(250 \times 4.6 \mathrm{~mm}$ i.d., Supelcosil LC-18, particle size $5 \mu \mathrm{m}$, Supelco Inc., Pasadena, $\mathrm{CA}$ ) by an autosampler, and separation of the dansyl derivatives was obtained using a linear methanol/water gradient changing from 65 to $100 \%$ methanol (Ratburn Chemicals Ltd, Walkerburn; HPLC grade) in $23 \mathrm{~min}$ at a flow rate of $1 \mathrm{ml} \mathrm{min}^{-1}$. Elution times for the internal standard and the dansyl derivatives of spermidine and spermine were $15.1,18.9$ and $22.5 \mathrm{~min}$, respectively. External standards were run after every seventh sample and contained $3.75,11.25$ and 3.75 pmol internal standard, spermidine and spermine, respectively. The assay sensitivity was $10 \mathrm{pmol}$ for the polyamines and the intra-assay coefficient of variation was $<4 \%$. The fluorescence detector was equipped with an excitation filter of $340 \mathrm{~nm}$ and an emission filter of $460 \mathrm{~nm}$.

\section{Determination of protein}

Protein was determined by the method of Lowry et al. (1951).

\section{Results}

The average segmental distribution of $\alpha$-glucosidase in epididymides obtained at necropsy is shown (Fig. 1). A general 


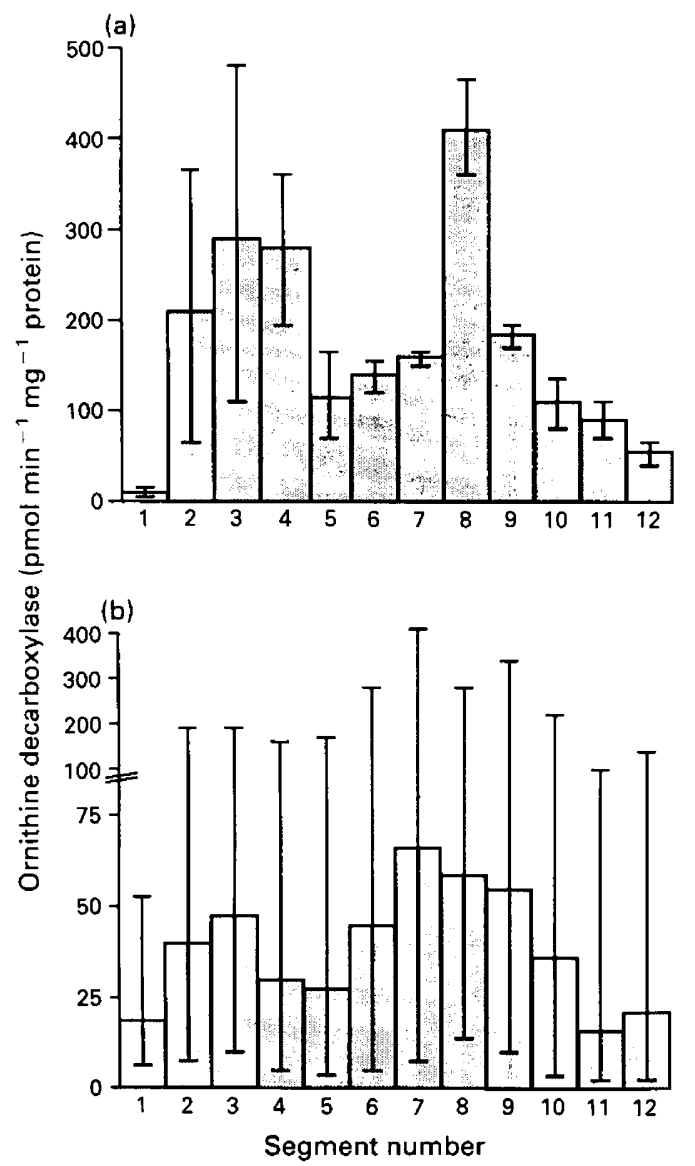

Fig. 3. The distribution of ornithine decarboxylase activity in the $20000 \mathrm{~g}$ supernatants of 12 epididymal segments from organs obtained (a) at necropsy (range; $n=2$ ) and (b) after orchidectomy (geometric means and $95 \%$ confidence limits; $n=4$ ).

increase in enzymic activity was apparent between segments 2 and 4 with a second increment in segments 6 and 7. Thereafter, there was a gradual decrease towards the vas deferens. These peaks in activity were more discernible in the fresh preparations removed after orchidectomy (Fig. 2). In subjects (a) and (b), the initial peak in the caput epididymis between segments 2 and 4 was localized primarily in the $20000 \mathrm{~g}$ supernatant. After a decline in the corpus area, a second increase in enzyme activity could be detected between segments 7 and 10 both in the tissue and the diluted epididymal secretion. The second peak in these fresh preparations was associated with more distal segments (7-10) than in the organs removed at autopsy (segments 6-9). In subject (c) (Fig. 2), although a caput enzyme peak could be detected, there was only a minor increase in activity in the caudal area in both the tissue and fluid compartments.

The activities of the ODC in the various segments of the epididymis are summarized (Fig. 3). Of the six epididymides examined, the two removed at necropsy (Fig. 3a) had markedly higher ODC activity than those removed at operation (Fig. 3b). However, the positions of the enzyme peaks were relatively constant and not influenced by the conditions of organ removal. Two peaks in activity could be demonstrated, in segments 3 and segments $7-8$. The first peak corresponded closely to
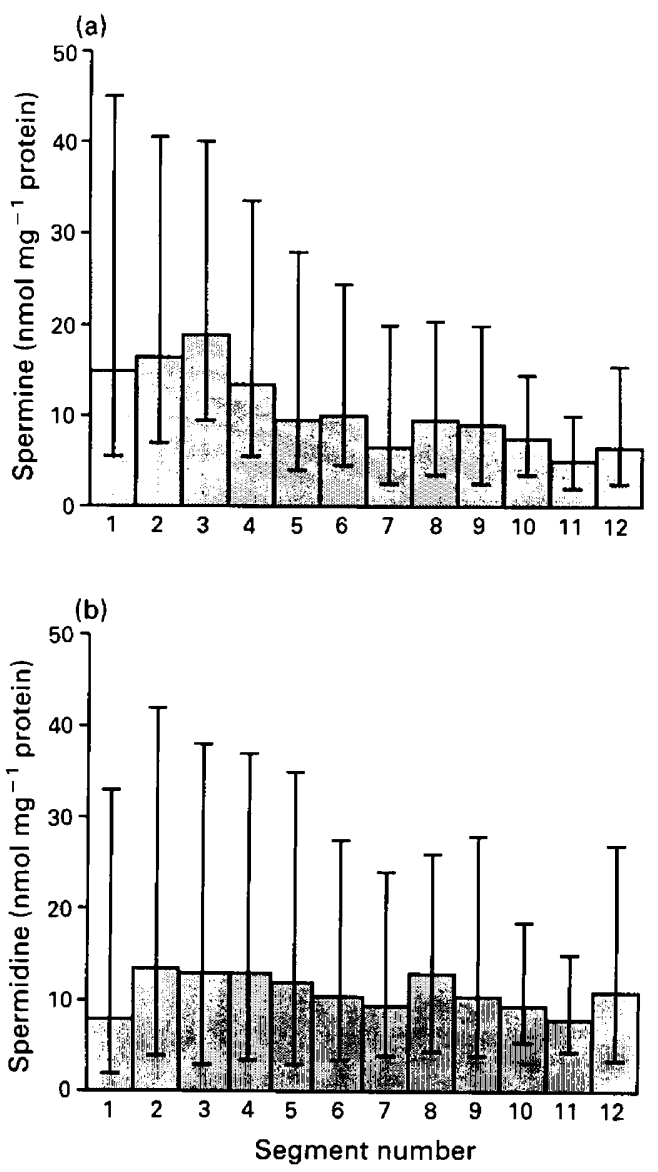

Fig. 4. The distribution of (a) spermine and (b) spermidine in the $20000 \mathrm{~g}$ supernatants of 12 epididymal segments (geometric means and $95 \%$ confidence limits; $n=7$ ) from organs obtained at necropsy.

the rise in tissue concentrations of spermidine and spermine measured in a different study using exclusively necropsy organs (Fig. 4). The second ODC peak, which in the majority of cases was higher than the first, was also associated with a secondary, albeit minor, increase in the tissue concentrations of both polyamines.

Correlation analyses of $\alpha$-glucosidase and polyamines in the same epididymal segments revealed highly significant positive associations between all three parameters $(\alpha$-glucosidase versus spermine: $r=0.41, P<0.001 ; \alpha$-glucosidase versus spermidine: $r=0.43, P<0.001$; spermine versus spermidine: $r=0.78$, $P<0.001$ ).

\section{Discussion}

Studies on the human epididymis suggest that histologically it can be subdivided into discrete segments (Holstein, 1980; Vendrely and Dadoune, 1988). The study reported here suggests that these histological divisions reflect regional differences in biochemistry. The finding that discrete regions in the caput and caudal segments of the epididymis exhibit increased ODC activities suggests a high degree of metabolic activity in 
these regions. This is also confirmed by corresponding alterations in the tissue concentrations of its metabolic products, spermidine and spermine. Previous unpublished studies failed to detect ODC activity in seminal plasma or in washed human spermatozoa, implying that the enzyme is intra-epithelial and not secreted into the epididymal lumen. In the study reported here it is not possible to conclude whether the polyamines are components of the epididymal secretion. Anatomical studies indicate that a major portion of the human caput epididymidis is composed of efferent ducts (Saitoh et al., 1990; Yeung et al., 1991). This increase in ODC activity can, therefore, reflect the transition from ductal cells to the secretory epithelium of the epididymal ducts. Results from a primate model indicate that there are significant regional differences in the epididymis with regard to $5 \alpha$-reductase and the concentration of androgen receptors, with the highest amounts recorded in the distal caput and corpus segments (Roselli et al., 1991). This initial peak in polyamine synthesis may therefore reflect increased androgen action in these proximal segments of the organ. Indeed, the higher activities of ODC in the necropsy specimens can be related to the relatively young age of the men and the androgen dependency of ODC. The secondary rise in activity of ODC in the caudal region suggests that, in addition to its function as a storage reservoir for spermatozoa, the caudal epithelium may also be actively involved in RNA and protein synthesis.

$\alpha$-Glucosidase, an acknowledged secretory product of the human epididymis (Guérin et al., 1986; Casano et al., 1987; Cooper et al., 1988), appears to be present in higher concentrations in the same distal caput segments as ODC (segments 3 and 4) and based on the washing studies is, apparently, predominantly intracellular. This supports the conclusions of Guérin and Czyba (1987), whose studies suggest that enzymic activity in the proximal segments of the epididymis reflects the acidic iso-enzyme. On the basis of histochemical studies and selective inhibition of the neutral form, the acid form appears to be primarily intracellular (Yeung et al., 1990). In contrast, the high activity in the caudal regions (segments 7-9) appears to be largely intraluminal since it appears in greater quantities in the tissue washings and as suggested by Yeung et al. (1990) presumably constitutes the neutral, secreted form of the enzyme. These neutral and acidic isoforms may represent unrelated biochemical entities with different functions or may simply reflect structural differences of the same enzyme associated with intracellular storage and secretion.

The reason why the second peak in $\alpha$-glucosidase activity is more proximal to the testis in the necropsy specimens than in the operated organs is unclear. It may be explained by a post-mortem diffusion of the epididymal luminal contents or may reflect the age difference of the subjects providing the operation and post-mortem specimens. In a previous study, the concentrations of carnitine in the human epididymis also appeared to be highest in a region closely corresponding to the segments 3-4 of the present study (designated Caput II; Bøhmer et al., 1978). Carnitine is also an acknowledged secretory product of the epididymis and has previously been used as a functional parameter (Wetterauer and Heite, 1978). The implication is that this area of the human epididymis may be of particular importance with regard to secretory processes and that any pathological lesions in these proximal segments may have detrimental consequences for sperm maturation. It may also explain recent reports of pregnancies after epididymovasostomies involving caput segments, where most of the epididymis is bypassed (Silber, 1989) and yet where spermatozoa can still acquire an adequate fertilizing ability.

\section{References}

Bedford JM (1975) Maturation, transport and fate of spermatozoa in the epididymis. In Handbook of Physiology Vol. 5 pp 1178-1180 Eds DW Hamilton and RO Greep. American Physiological Society, Washington

Behmer T, Hoel P, Purvis K and Hansson V (1978) Carnitine levels in human accessory sex organs Archives of Andrology 1 53-59

Casano R, Orlando C, Caldini AL, Barni T, Natali A and Serio M (1987) Simultaneous measurement of seminal L-carnitine, alpha-1, 4-glucosidase and glycerylphosphorylcholine in azoospermic and oligospermic patients Fertility and Sterility 47 324-328

Chapdelaine P, Tremblay RR and Dubé JY (1978) p-Nitro-phenol- $\alpha$-D-glucopyranoside as substrate for measurement of maltase activity in human semen Clinical Chemistry 24 208-211

Cooper TG, Yeung CH, Nashan D and Nieschlag E (1988) Epididymal markers in male infertility Journal of Andrology 9 91-101

Fournier-Delpech S and Courot M (1987) Sperm-zona pellucida binding activity Oxford Reviews of Reproductive Biology 9 294-321

Gagnon C, Harbour D, de Lamirande E, Bardin CW and Dacheux J-L (1984) Sensitive assay detects protein methyltransferase in spermatozoa: decrease in enzyme activity during epididymal maturation Biology of Reproduction 30 953-958

Guérin JF and Czyba JC (1987) Hydrolytic enzymes detected in fluid and in spermatozoa from different portions of the human epididymis. In Morphological Basis of Human Reproductive Function, pp 197-200 Eds G Spera and DM De Kretser. Plenum Press, London

Guérin JF, Benal H, Rolletz J, Soucher C and Czyba JC (1986) Alpha-glucosidase as a specific epididymal enzyme marker - its validity for the etiologic diagnosis of azoospermia Journal of Andrology 7 156-162

Holstein AF (1980) Die Morphologie des Nebenhodens beim Menschen. In Physiologie und Pathophysiologie des Nebenhodens und der Samenblase. 3. Casteiner Colloquium, pp 1-14 Eds T Senge, F Neumann and UW Tunn. Georg Thieme, Stuttgart

Kobayashi Y, Kupelian J and Maudsley DV (1971) Ornithine decarboxylase stimulation in rat ovary by luteinizing hormone Science 172 379-380

Lowry OH, Rosebrough NJ, Farr AL and Randall RJ (1951) Protein measurement with the folin phenol reagent Journal of Biological Chemistry 193 265-275

Olson GE and Danzo BJ (1981) Surface changes in rat spermatozoa during epididymal transit Biology of Reproduction 24 431-443

Pegg AE, Lockwood DH and Williams-Ashman HG (1970) Concentrations of putrescine and the polyamines and their enzymic synthesis during androgeninduced prostatic growth Biochemical Joumal 117 17-31

Purvis K, Cusan L, Attramadal H, Ege A and Hansson V (1982) Rat sperm enzymes during epididymal transit journal of Reproduction and Fertility 65 $381-387$

Purvis K, Haug E, Thomassen Y, Mevaig B and Rui H (1986) Short-term effects of mating on the accessory sex glands of the male rat Journal of Reproduction and Fertility 77 373-380

Roselli CE, West NB and Brenner RM (1991) Androgen receptor and $5 \alpha$-reductase activity in the ductuli efferentes and epididymis of adult rhesus macaques Biology of Reproduction 44 739-745

Ross P, Kan FW, Antaki P, Vigneault N, Chapdelaine A and Roberts KD (1990) Protein synthesis and secretion in the human epididymis and immunoreactivity with sperm antibodies Molecular Reproduction and Development 26 12-23

Rui H and Purvis K (1987) Prolactin selectively stimulates ornithine decarboxylase in the lateral lobe of the rat prostate Molecular and Cellular Endocrinology $\mathbf{5 0}$ 89-97

Rui H, Haug E, Mevag B, Thomassen Y and Purvis K (1985) Short-term effects of prolactin on prostatic function in rats with lisuride-induced hyperprolactinaemia Joumal of Reproduction and Fertility 75 421-432

Russell DH (1980) Omithine decarboxylase as a biological and pharmacological tool Pharmacology 20 117-136

Saitoh K, Terada T and Hatakayama S (1990) A morphological study of the efferent ducts of the human epididymis International Joumal of Andrology 13 $369-376$ 
Silber SJ (1989) Role of the epididymis in sperm maturation Urology 33 47-51 Sylvester SR, Skinner MK and Gyiswold MD (1984) A sulfated glycoprotein synthesized by Sertoli cells and by epididymal cells is a component of the sperm membrane Biology of Reproduction 31 1087-1101

Vendrely E and Dadoune JP (1988) Quantitative ultrastructural analysis of the principal cells in the human epididymis Reproduction Nutrition and Development 28 1225-1235

Voglmayr JK (1975) Metabolic changes in spermatozoa during epididymal transit. In Handbook of Physiology Vol. 5 pp 437-451 Eds DW Hamilton and RO Greep. American Physiological Society, Washington
Wetterauer $\mathrm{U}$ and Heite HJ (1978) Carnitine in seminal fluid as a parameter for epididymal functions Andrologia 10 203-208

Yeung CH, Copper TG and Senge T (1990) Histochemical localization and quantification of $\alpha$-glucosidase in the epididymis of men and laboratory animals Biology of Reproduction 42 669-676

Yeung CH, Cooper TG, Bergmann M and Schultze H (1991) Organization of tubules in the human caput epididymidis and the ultrastructure of their epithelia American Journal of Anatomy 191 261-279 